\title{
POLITIK HUKUM MAHKAMAH KONSTITUSI ATAS REKOGNISI PENGHAYAT KEPERCAYAAN DALAM KONTESTASI POLITIK KEWARGAAN INDONESIA
}

\author{
M. Wildan Humaidi
}

Fakultas Syariah IAIN Purwokerto

Jalan Ahmad Yani No. 40 A Purwokerto, Kab. Banyumas, Jawa Tengah

Email: wildanhumaidi@iainpurwokerto.ac.id

\begin{abstract}
Freedom of belief and religion is an instrument of international human rights, as also guaranteed in Article $28 \mathrm{E}$ and Article 29 of the 1945 Constitution. In Fact, the Government has discriminated by only giving recognition and protection to six religions: Islam, Christianity, Catholicism, Buddhism, Hindus, and Confucians, while advocates of belief in God Almighty do not receive recognition and protection, because they are not "religious". Through the judicial review mechanism of the Population Administration Law, the Constitutional Court has reconstructed the concept of the recognition of religion and belief in the population administration system as a space for the contestation of citizenship politics. The Court emphasized that the followers of trust have the same rights as followers of six official religions in Indonesia in fulfilling the rights of citizens. This paper seeks to elaborate on the legal politics of the Constitutional Court on the recognition of supporters of trust in the politics of citizenship.
\end{abstract}

\section{Keywords:}

The Believer of Trust; Right to Freedom of Religion and Belief; Decision of the Constitutional Court.

\begin{abstract}
Abstrak
Kebebasan berkeyakinan dan beragama merupakan instrument hal asasi manusia internasional, sebagaimana juga dijamin dalam Pasal 28 E dan Pasal 29 UUD 1945. Namun dalam realitanya, Pemerintah telah melakukan diskriminasi dengan hanya memberikan pengakuan dan perlindungan terhadap enam agama: Islam, Kristen, Katolik, Budha, Hindu, dan Khonghucu, sedangkan penghayat kepercayaan terhadap Tuhan Yang Maha Esa tidak mendapat pengakuan dan perlindungan, karena dinilia tidak "beragama". Melalui mekanisme judicial review UU Administrasi Kependudukan, Mahkamah Konstitusi telah merekonstruksi konsep pengakuan agama dan kepercayaan dalam sistem administrasi kependudukan sebagai ruang kontestasi
\end{abstract}


politik kewarganegaraan. MK menegaskan bahwa penghayat kepercayaan memiliki hak yang sama dengan penganut enam agama resmi yang ada di Indonesia dalam pemenuhan hak warga negara. Tulisan ini berupaya mengelaborasi politik hukum Mahkamah Konstitusi atas rekognisi penghayat kepercayaan dalam politik kewargaan.

Kata Kunci:

Penghayat Kepercayaan; Hak Kebebasan Beragama dan Berkeyakinan; Putusan Mahkamah Konstitusi.

\section{A. PENDAHULUAN}

Keberagaman suku bangsa, budaya, bahasa, dan agama yang dimiliki Negara Indonesia merupakan entitas kebangsaan dan sekaligus merupakan sumber kekayaan yang tidak ternilai harganya. Salah satu wujud budaya Indonesia tersebut adalah budaya spiritual yang berakar pada kepercayaan terhadap Tuhan Yang Maha Esa. Kepercayaan bangsa Indonesia terhadap Tuhan Yang Maha Esa sebagaimana dinyatakan secara tegas dalam rumusan sila Pertama Pancasila dan telah dituangkan dalam batang tubuh Undang-Undang Dasar (UUD) Negara Republik Indonesia, telah menjamin secara penuh warganya untuk memeluk dan mempercayai sistem agama dan kepercayaannya masing-masing, sebagaimana termaktub dalam ketentuan Pasal 29 Ayat (2) UUD NRI Tahun 1945.

Keberadaan kepercayaan terhadap Tuhan Yang Maha Esa sudah ada sejak dahulu sebelum agama-agama formal masuk ke Indonesia. Dalam kenyataannya, kepercayaan terhadap Tuhan Yang Maha Esa ini melahirkan adanya aliran penghayat kepercayaan yang juga disebut sebagai aliran kebatinan. ${ }^{1}$ Sampai sekarang ini jumlah penghayat kepercayaan berkisar dua belas juta orang, yang seluruhnya tersebar di semua daerah di Indonesia. ${ }^{2} \mathrm{Di}$ antaranya Kelompok Kepercayaan Kaharingan di Kalimantan, Sunda Wiwitan di Jawa Barat dan Banten, Parmalim di Sumatera Utara, dan masih banyak yang lain.

Dalam konstelasinya, konsep agama sering kali diidentikkan oleh sebagian orang memiliki kesamaan dengan konsep kepercayaan, atau setidak-tidaknya

1 Aliran kebatinan atau dikenal dengan "kepercayaan", (lengkapnya kepercayaan terhadap Tuhan Yang Maha Esa adalah suatu sistem kepercayaan atau sistem spiritual yang ada di Indonesia selain agama, aliran, paham, sekte atau madzhab dari agama tersebut, serta bukan pula termasuk kepercayaan adat. IGM Nurdjana, Hukum Dan Aliran Kepercayaan Menyimpang Di Indonesia [Yogyakarta: Pustaka Pelajar, 2009], 21.

2 Prins David Saut, "Ada 187 Organiasasi dan 12 Juta Penghayat Kepercayaan di Indonesia," Detik.com, November 9, 2017, https://news.detik.com/berita/3720357/ada-187-organisasi-dan-12juta-penghayat-kepercayaan-di-indonesia. 
memiliki kemiripan. ${ }^{3}$ Penganut agama dan penganut kepercayaan sama-sama mempunyai sistem keyakinan (teologi) yang tidak bisa dibedakan. Menganut agama dan menganut kepercayaan merupakan ekspresi dari sebuah keyakinan yang transenden. ${ }^{4}$ Hakikat kesamaan konseptual tersebut dapat ditelusuri melalui terminologi, kebahasaan serta dokumen hukum HAM Internasional. Wilfred Cantwel Smith mengatakan bahwa hakikat agama (agama yang dimaksud semua sistem keyakinan) adalah iman (faith). Pengertian Iman menurut Smith: "standard man is man of faith", dan "faith as a global human characteristic is man's responsive involvement in the activity of God's dealing with humankind." 5 Sedangkan dalam hukum HAM, Pasal 28 E Ayat (2) UUD NRI Tahun 1945 menyatakan bahwa setiap orang berhak atas kebebasan meyakini kepercayaan, menyatakan pikiran, dan sikap sesuai hati nuraninya. Dan diperkuat lagi dalam Pasal 29 Ayat (2) UUD NRI Tahun 1945 yang menyatakan negara menjamin kemerdekaan setiap orang memeluk agamanya masing-masing dan kepercayaannya itu.

Pengakuan sebagaimana diamanahkan dalam konstitusi Pasal 28 E Ayat (2) dan Pasal 29 Ayat (2) tersebut merupakan bentuk akomodasi negara terhadap aliranaliran kepercayaan di berbagai daerah di Nusantara atau yang bisa disebut sebagai kepercayaan lokal. Kepercayaan lokal dengan sistem ajaran, tradisi, dan pengikut merupakan suatu entitas kewargaan (citizenship) yang hidup dalam masyarakat hingga sekarang, sebagai suatu warisan budaya dari nenek moyang bangsa Indonesia yang lahir jauh sebelum agama formal datang di Indonesia. Selain itu, kebebasan beragama dan berkeyakinan juga merupakan bagian dari hak sipil dan politik yang menjadi bagian instrumen Hak Asasi Manusia (HAM) yang dijamin oleh konstitusi. ${ }^{6}$

Pada kenyataannya, di Indonesia terdapat 6 agama yag diakui keberadaannya antara lain Islam, Kristen, Katolik, Hindu, Budha, dan Khonghucu. ${ }^{7}$ Kebijakan

3 "Dokumen International Convenant on Civil and Political Right," § Pasal 18 (n.d.) kata agama dan keyakinan disebut sejajar dengan kata "atau" (religion or belief). Lihat dalam Komentar Umum 22 Paragraf 2 Pasal 18 ICCPR.

${ }^{4}$ Konsep agama dikerangkakan sebagai berikut; Pertama, Keyakinan akan Tuhan atau "yang tertinggi"; Kedua, sebuah pandangan menyeluruh mengenai dunia dan tujuan manusia-manusia; Ketiga, kepercayaan mengenai kehidupan setelah mati; keempat, komunikasi dengan "Tuhan" melalui Ibadah dan doa; kelima, perspektif tertentu mengenai kewajiban moral yang berasal dari kode moral atau konsepsi mengenai sifat Allah; keenam, praktik-praktik yang melibatkan pertobatan dan pengampunan dosa; ketujuh, perasaan keagamaan mengenai kekaguman, rasa bersalah dan penyembahan; kedelapan, penggunaan teks-teks suci; kesembilan, organisasi untuk memfasilitasi aspek korporasi dari praktik-praktik agama dan untuk mempromosikan dan melanggengkan praktikpraktik dan kepercayaan tertentu. Lucy Vickers, Religious Freedom, Religious Discrimination and the the Workplace (USA: Hart Publishing, 2008), 18.

${ }^{5}$ Wilfred Cantwel Smith, The Meaning and End of Religion (Virginia: Macmillan, 1963), 48-50.

6 Pasal 28 I Ayat (1) dan (2). “Undang-Undang Dasar Negara Kesatuan Republik Indonesia Tahun 1945," § Pasal 28 (n.d.).

7 "Pencegahan Penyalahgunaan Dan/Atau Penodaan Agama," Pub. L. No. Penetapan Presiden No. 1 Tahun 1965, § Pasal 1 (n.d.). 
negara atas "agama" dan "kepercayaan" tersebut dinilai telah, atau setidak-tidaknya berpotensi, menimbulkan praktik diskriminasi. Negara telah melakukan diskriminasi dalam bentuk favorutism, ${ }^{8}$ dengan memberikan pengakuan dan perlindungan terhadap 6 agama tersebut, sedangkan penghayat kepercayaan terhadap Tuhan Yang Maha Esa tidak mendapat pengakuan dan perlindungan, karena dianggap tidak "beragama". ${ }^{9}$ Para penghayat kepercayaan yang jumlahnya jutaan tidak dapat diproses pencatatannya melalui sistem Kartu Tanda Penduduk (KTP) elektronik, sebagaimana diatur dalam Pasal 61 Ayat (1) dan (2) UU No. 23 Tahun 2006 Tentang Administrasi Kependudukan, karena dinilai tidak masuk dalam kualifikasi enam agama "resmi". Padahal KTP adalah tanda kependudukan yang harus diberikan kepada seluruh warga negara, sekaligus menjadi akses kunci politik kewargaan.

Berdasarkan realita tersebut, Nggay Mehang Tana, Pagar Demanra Sirait, Arnol Purba, dan Carlim mengajukan judicial review ke Mahkamah Konstitusi (MK). MK, sebagai pengawal HAM (the guardian of the human rights), melalui Putusan No. 97/PUU-XIV/2016 mengabulkan permohonan judicial review terkait pengosongam kolom agama bagi penganut atau penghayat kepercayaan. Melalui putusan tersebut, MK telah mengoreksi garis politik hukum Negara terhadap eksistensi penghayat kepercayaan yang sejatinya telah melenceng jauh dari jalur konstitusional. MK telah merekonstruksi konsep pengakuan (rekognisi) agama dan kepercayaan dalam sistem administrasi kependudukan sebagai ruang kontestasi politik kewargaan yang selama ini dinilai diskriminatif. Melalui putusannya, MK menegaskan bahwa penghayat kepercayaan memiliki hak yang sama dengan penganut enam agama resmi yang ada di Indonesia dalam hal pencatatan status keagamaannya di Kartu Tanda Penduduk.

Penelitian ini berupaya mengelaborasi dua hal pokok problem utama pengakuan penghayat kepercayaan dan relevansinya dengan politik kewargaan. Yakni; Pertama, perihal politik hukum negara dalam mengatur eksistensi penghayat kepercayaan di Indonesia, dan Kedua, perihal politik hukum HAM Mahkamah Konstitusi atas rekognisi pengakuan penghayat kepercayaan serta implikasinya terhadap kontestasi politik kewargaan di Indonesia.

\section{B. METODE PENELITIAN}

Untuk mengkaji pokok permasalahan, penelitian ini menggunakan metode penelitian hukum normatif. Dengan meneliti bahan pustaka yang ada serta Putusan MK yang kemudian dianalisis dengan metode interpretasi untuk memberikan

8 Favorutism adalah perilaku atau sikap kecenderungan untuk memihak pada satu kelompok tertentu dan memunculkan sikap positif terhadap kelompok tersebut dan sikap negative pada kelompok lain. Asep Alimin and M. Ariez Musthofa, "Hubungan Antara Ingroup Favoritism Dan Perilaku Sosial," Jurnal Psikologi Insight 3, no. 1 (April 2019): 32-45.

9 Oki Wahju, "Penghormatan Hak Asasi Manusia Bagi Penghayat Kepercayaan Di Kota Bandung" 7, no. 1 (July 2016): 37. 
gambaran-gambaran, serta pola rekognisi penghayat kepercayaan dalam kontestasi politik kewarganegaraan di Indonesia. Penelitian ini menggunakan dua metode pendekatan, yaitu; Metode pendekatan perundang-undangan (statue approach) dan pendekatan kasus (case approach). Pertama, pendekatan perundang-undangan (statue approach), ${ }^{10}$ digunakan dalam menelusuri undang-undang yang mengatur tentang eksistensi penghayat kepercayaan. Kedua, Pendekatan kasus, 11 digunakan untuk melihat serta menganalisis pertimbangan haikm (ratio decidenci) $\mathrm{MK}$ dalam melakukan rekonsepi pengakuan penghayat kepercayaan dan implikasinya dalam ruang kontestasi politik kewargaan.

Sumber data primer yang digunakan adalah Undang-Undang Dasar NRI Tahun 1945, UU No. 23 tahun 2006 tentang Administrasi Kependudukan dan Putusan Mahkamah Konstitusi No. 97/PUU-XIV/2016, serta beberapa regulasi Negara yang berkaitan dengan pengaturan penghayat kepercayaan. Sedangkan sumber data sekunder berupa literasi kajian ilmiah yang relevan dengan penelitian ini. Sebagai upaya menemukan jawaban dan simpulan dari problem penelitian ini, data-data penelitian tersebut dianalisis berdasarkan teknik reduksi data.

\section{HASIL DAN PEMBAHASAN}

\section{Konsep Penghayat Kepercayaan}

Penghayat kepercayaan dalam beberapa terma juga sering disebut dengan istilah aliran kepercayaan. Terdapat beragam pendapat perihal apa sebenarnya aliran kepercayaan. Namun demikian, perbedaan tersebut telah menemukan titik temu pada satu kesimpulan yang menyatakan bahwa aliran kepercayaan merupakan kepercayaan asli bangsa Indonesia, eksistensi mereka ada sebelum negara ini berdaulat. Secara sederhana, aliran kepercayaan dapat dimaknai sebagai pernyataan dan pelaksanaan hubungan pribadi dengan Tuhan Yang Maha Esa, berdasarkan keyakinan yang diwujudkan dengan perilaku ketakwaan terhadap Tuhan Yang Maha Esa atau peribadatan serta pengalaman budi luhur.

Dalam terminologi Bahasa Indonesia, aliran kepercayan mengalami berbagai pengistilahan atau penamaan. Penamaan yang terbaru adalah "penghayat kepercayaan",12 sebelumnya populer dengan istilah "Kepercayaan terhadap Tuhan Yang Maha Esa" atau "Kepercayaan". Penamaan terhadap aliran kepercayaan terus mengalami pergeseran sesuai dengan kondisi dan zaman yang melingkupinya. Pada

10 Salim HS and Erlies Septiana, Penerapan Teori Hukum Pada Penelitian Tesis Dan Disertasi (Jakarta: Rajawali Pers, 2013), 131.

11 HS and Septiana, 134.

12 Pasal 61 ayat (2) dan Pasal 64 ayat (2) "Undang-Undang Nomor 24 Tahun 2013 Atas Perubahan Undang-Undang Nomor 23 Tahun 2006 Tentang Administrasi Kependudukan," Pub. L. No. UU No. 24 Tahun 2013 jo No. 23 Tahun 2016, § Pasal 61 Ayat (2); Pasal 64 Ayat (2) (n.d.). 
awalnya, sebelum Indonesia berdaulat, istilah kepercayaan populer dengan penamaan kepercayaan dan kebatinan, penggunannya silih berganti. Pada zaman revolusi kemerdekaan disebut dengan penamaan "klenik" dan pada masa setelah kemerdekaan sampai pada tahun 1970-an dikenal dengan sebutan "kebatinan yang meninggi". Kemudian menjelang sidang Umum Majelis Permusyawaratan Rakyat pada tahun 1973 poluler dengan sebutan "Kepercayaan". ${ }^{13}$ Pergeseran dan sering bergantinya peristilahan terhadap aliran kepercayaan ini disebabkan oleh kebijakan pemerintah yang juga sering kali menggunakan istilah yang berbeda-beda dalam menyebut aliran kepercayaan. ${ }^{14}$

Secara terminologis, istilah "kepercayaan" merupakan sebutan yang dilekatkan kepada sebuah sistem religi di Indonesia yang tidak termasuk bagian dari salah satu agama-agama resmi. ${ }^{15}$ Sebelum lebih popular dengan sebutan "Kepercayaan terhadap Tuhan yang Maha Esa," konsep kepercayaan terhadap Tuhan Yang Maha Esa dikenal dengan istilah "kepercayaan" atau disebut juga sebagai "kebatinan".16 Term "kepercayaan" lebih dahulu diperkenalkan dalam konsep sejarah legal konstitusional oleh KRMT Wongsonegoro dalam sidang Badan Penyelidik Usaha-Usaha Persiapan Kemerdekaan Indonesia (BPUPKI) pada tanggal 13 Juli 1945.17 Belakangan kemudian, Pemerintah melalui Departemen Agama menggunakan terma "aliran kepercayaan" ketika mendirikan Biro PAKEM (Pengawas Aliran Kepercayaan Masyarakat). ${ }^{18}$

Menurut sejarah perkembangan aliran kepercayaan di tanah air, jumlah dan macamnya selalu mengalami eskalasi pasang surut. Masing-masing aliran kepercayaan mempunyai ciri khusus yang berbeda dengan yang lainnya. Oleh karena itu, seperti halnya agama, nampaknya sulit untuk memberikan suatu definisi secara komprehensif. Pengertian etimologi mungkin dapat diuraikan, namun belum menggambarkan pengertian terminologi sebagai bangunan definisi konseptual yang

13 Mohammad Damami, Kepercayaan Terhadap Tuhan Yang Maha Esa Periode 1973-1983; Sebuah Sumbangan Pemahaman Tentang Proses Legalisasi Konstitusional Dalam Konsteks Pluralitas Keberagaman Di Indonesia (Jakarta: Kementerian Agama, 2011), 8.

14 Mohammad Damami, Kepercayaan Terhadap Tuhan Yang Maha Esa Dewasa Ini (Yogyakarta: Pustaka Pelajar, 2018), 63.

15 Tim Penyusun Kamus Pusat Bahasa, “Kamus Besar Bahasa Indonesia” (Jakarta: Pusat Bahasa Departemen Pendidikan Nasional, 2018).

16 Ahmad Chairul Rofiq, "Ahmad Chairul Rofiq, Kebijakan Pemerintah Terkait Hak Sipil Penghayat Kepercayaan Dan Impikasinya Terhadap Perkembangan Penghayat Kepercayaan Di Ponorogo," Kodifikasia 8, no. 1 (2014): 3.

17 Damami, Kepercayaan Terhadap Tuhan Yang Maha Esa Periode 1973-1983; Sebuah Sumbangan Pemahaman Tentang Proses Legalisasi Konstitusional Dalam Konsteks Pluralitas Keberagaman Di Indonesia, 55-56.

18 Damami, 58. 
total. Aliran kepercayaan dapat disebut aliran kebatinan, kerohaniaan, kejiwaan, kejawen, dan lain sebagainya.

Jika berangkat dari pembahasan etimologis, aliran kepercayaan terdiri dari dua suku kata "Aliran dan Kepercayaan". Aliran berarti haluan, pendapat, paham (pandangan hidup, politik, dan sebagainya). ${ }^{19}$ Sedangkang "pengahayat" asal katanya adalah hayat, yang berarti hidup. Makna dari kepercayaan itu sendiri adalah orang yang menghayati. Sedangkan Kepercayaan, berasal dari kata "percaya" yang berarti mengakui atau yakin bahwa sesuatu memang benar atau nyata, mendapat imbuhan awalan "ke" dan akhiran -“an" yang bermakna iman, sehingga dapat diartikan bahwa kepercayaan adalah anggapan atau keyakinan bahwa sesuatu yang dipercayai itu benar atau nyata. Berdasarkan etimologi di atas, aliran kepercayaan adalah suatu paham yang mengakui terhadap kebenaran atas suatu hal. Sedangkan penghayat kepercayaan adalah orang yang meyakini atas suatu hal. Jadi dapat disimpulkan antara istilah aliran kepercayaan dan penghayat kepercayaan menunjukkan pemaknaan yang sama.

Dalam perkembangan selanjutnya, istilah aliran kepercayaan bukanlah diartikan terpisah, tetapi dirangkai menjadi satu kesatuan, yaitu "aliran kepercayaan". Pengertian aliran kepercayaan yang dimaksud adalah semua aliran kepercayaan yang ada dalam masyarakat dan berkeyakinan terhadap Tuhan Yang Maha Esa.

Seperti diuraikan sebelumnya, pengistilahan atau penamaan aliran kepercayaan diistilahkan dengan beragam oleh sejumlah ahli. Sebagian ada yang menyebutnya sebagai Agama Asli, Agama Budaya, Aliran Kebatinan, bahkan ada menyebutnya Aliran Kerohanian. Kamil Kartapradja menyebut kepercayaan dengan istilah aliran kepercayaan. Menurutnya, aliran kepercayaan adalah keyakinan dan kepercayaan rakyat Indonesia di luar agama dan tidak termasuk ke dalam salah satu agama. Kamil Kartapradja juga mengartikan kebatinan sebagai gerak badan jasmani disebut olah raga dan gerak badan rohani dinamai olah batin atau kebatinan. Kebatinan dapat disimpulkan sebagai olah batin yang bermacam-macam bentuknya. ${ }^{20}$ Sedangkan Sumantri Mertodipuro dengan berangkat dari fungsi dan tujuannya sebuah kepercayaan, menjelaskan bahwa kepercayaan adalah cara keyakinan orang Indonesia mendapatkan kebahagiaan. Kebahagiaan tersebut dapat diwujudkan dengan menempuh jalan tasawuf, ilmu kesempurnaan, theosofi, mistik, serta gejala kebatinan yang lain. ${ }^{21}$

19 “Kamus Besar Bahasa Indonesia."

20 Kamil Kartapradja, Aliran Kebatinan Dan Kepercayaan Di Indonesia (Jakarta: Masagung, 1985), 61.

21 Rahmat Subagya, Kepercayaan (Kebatinan, Kerohanian, Kejiwaan) Dan Agama (Yogyakarta: Kanisius, 1976), 21. 
Rahmat Subagya menyebut kepercayaan sebagai "agama asli" Indonesia. Menurutnya bahwa kepercayaan merupakan bentuk kebatinan yang didefinisikan dengan suatu ilmu atas dasar ketuhanan absolut, yang mempelajari kenyataan dan mengenal hubungan langsung dengan Tuhan tanpa adanya perantara. ${ }^{22}$ Selain itu, beberapa pakar juga berpendapat bahwa aliran kepercayaan sama maknanya dengan aliran kebatinan. M.M. Djojodigoeno mengkualifikasikan bahwa sebuah kepercayaan atau aliran kebatinan tersebut mempunyai empat unsur; ilmu ghaib, union mistik, "sangkan paraning dumadi" dan budi luhur. Menurut H.M. Rasyidi bahwa kata "batin" diartikan sebagai bagian yang dalam dan tersembunyi. Istilah batin dapat dimaknai sebagai orang-orang yang mencari arti yang dalam dan tersembunyi dalam kitab suci. Mereka mengartikan kata-kata itu tidak menurut bunyi hurufnya tetapi menurut interpretasi sendiri. ${ }^{23}$

Kepala Biro Politik Departemen dalam Negeri tahun 1952 sampai 1962, menjelaskan arti aliran kepercayaan yaitu keyakinan dan kepercayaan rakyat Indonesia di luar agama dan tidak termasuk ke dalam aliran salah satu agama. Aliran kepercayaan itu ada dua macam yakni yang pertama kepercayaan yang sifatnya tradisional dan animistis, tanpa filosofi dan tidak ada pelajaran mistiknya, yang kedua golongan kepercayaan yang ajarannya ada filosofinya, juga disertai mistik, golongan inilah yang menyebut dirinya sebagai golongan kebatinan. Golongan kebatinan ini dalam perkembangannya akhirnya menamakan dirinya sebagai golongan kepercayaan kepada Ketuhanan Yang Maha Esa. ${ }^{24}$

PAKEM (Pengawas Aliran Kepercayaan Masyarakat) dalam pokok-pokok pola pelaksanaan tugas, menyebutkan yang dimaksud dengan aliran kepercayaan dalam masyarakat mencakup:25

Aliran keagamaan meliputi: Sekte keagamaan, gerakan keagamaan, pengelompokan jemaah keagamaan, baik agama langit maupun agama bumi; Kepercayaan budaya meliputi: Aliran-aliran kebatinan, kejiwaan, kerohanian/keper cayaan terhadap Tuhan Yang Maha Esa dan sebagainya. Mistik, kejawen, pedukunan, peramalan, paranormal, metafisika.

Aliran keagamaan sumber utamanya adalah kitab suci berdasarkan wahyu Tuhan, sedangkan aliran kepercayaan sumber utamanya adalah budaya bangsa yang mengandung nilai-nilai spiritual/kerohanian yang hidup dan telah membudaya dalam masyarakat sebagai hasil penalaran daya, iptarasa, karsa dan hasil karya manusia.

22 Subagya, 189.

${ }^{23}$ HM Rasyidi, Islam Dan Kebatinan (Jakarta: Yayasan Islam Studi Club Indonesia, 1967), 49.

${ }^{24}$ Kartapradja, Aliran Kebatinan Dan Kepercayaan Di Indonesia, 1.

${ }^{25}$ Kejaksaan Agung RI, Pokok-Pokok Pola Pelaksanaan Tugas Pakem (Jakarta: Kejaksaan Agung RI, 1985), 3. 
Jika merujuk makna kepercayaan dalam rumusan Undang-undang, tidak dijelaskan definisi penghayat kepercayaan, sekalipun sering disebut dalam peraturan perundang-undangan. Setidaknya, penjelasan perihal penghayat kepercayaan terdapat dalam PP Nomor 37 Tahun 2007 sebagai Pelaksanaan UU Nomor 23 Tahun 2006 Tentang Administrasi Kependudukan. Penghayat terhadap Tuhan Yang Maha Esa, selanjutnya yang disebut Penghayat Kepercayaan adalah setiap orang yang mengakui dan meyakini nilai-nilai penghayatan kepercayaan terhadap Tuhan Yang Maha Esa. ${ }^{26}$ Kategori ini sepertinya juga tidak menegaskan perbedaan antara "kepercayaan", "agama lokal”, "kepercayaan lokal”, dan "agama tradisional" ${ }^{27}$

\section{Pengakuan Terhadap Penghayat Kepercayaan sebagai Instrumen HAM}

Hal yang paling fundamental dalam pembahasan pengakuan terhadap penghayat kepercayaan adalah aspek Hak Asasi Manusia (HAM). Sedangkan konsep pengakuan terhadap penghayat kepercayaan merupakan wujud manifestasi dari adanya jaminan HAM, khususnya hak atas kebebasan berkeyakinan, yang seringkali disandingkan dengan kebebasan beragama. Terdapat beberapa pengaturan atas hak kebebasan beragama dan berkeyakinan sebagai basis legitimasi sekaligus landasan filosofis atas konsep jaminan pengakuan yang ditegaskan dalam dokumen HAM.

Keberadaan hak kebebasan berkeyakinan dan beragama merupakan salah satu pondasai prasyarat dalam masyarakat pluralistik dan demokratik di dalam masyarakat internasional. ${ }^{28}$ Kebebasan internasional telah menjamin kebebasan beragama, termasuk membolehkan semua kepercayaan dan bahkan kebebasan untuk tidak mempercayai apapun juga. Oleh karenanya, kebebasan ini mencakup semua agama besar, agama lokal, sistem kepercayaan, dan termasuk agnostik dan ateis. $^{29}$

Dalam dokumen Deklarasi Universal Hak Asasi Manusia (DUHAM) dijelaskan bahwa semua hak-hak yang terdapat di dalam deklarasi HAM dapat dinikmati oleh semua orang tanpa terkecuali, tanpa membeda-bedakan agama dan keyakinan yang dianutnya. Secara tegas, Pasal 18 DUHAM menyebutkan bahwa "Setiap orang berhak atas kebebasan, pikiran, hati nurani dan agama,; hak ini mencakup

${ }^{26}$ Pasal 1 Nomor 19 "Peraturan Pemerintah (PP) Tentang Pelaksanaan Undang Undang Nomor 23 Tahun 2006 Tentang Administrasi Kependudukan," Pub. L. No. PP No 37 Tahun 2007, § Pasal 1 (n.d.).

27 Iqbal Hasanuddin, "Hak Atas Kebebasan Beragama/Berkeyakinan: Sebuah Upaya Pendasaran Filosofis," SOCIETAS DEI 4, no. 1 (April 2017): 97-98.

28 Mashood A Baderin, Hukum Hak Asasi Manusia Dan Hukum Islam (Jakarta: Komisi Nasional Hak Asasi Manusia, 2010), 121.

${ }^{29}$ Rhoma K.M. Smith, Hukum Hak Asasi Manusia (Yogyakarta: PUSHAM UII, 2008), 106. 
kebebasan untuk mengubah agama atau kepercauaan, dan kebebasan untuk menjalankan agama atau kepercayaannya dalam pengajaran, praktik, ibadat, dan kekhidmatan, baik sendiri maupun bersama-sama dengan orang lain, di muka umum maupun sendiri."

Kebebasan beragama dan berkeyakinan juga diatur dalam Konvenan Internasional Hak Sipil dan Politik. Secara tegas, Pasal 18 menyatakan "Setiap orang berhak atas kebebasan berpikir, keyakinan dan beragama. Hak ini mencakup kebebasan untuk menetapkan agama atau kepercayaan atas pilihannya sendiri, dan kebebasan, baik sendiri maupun bersama-sama dengan orang lain, baik di tempat umum atau tertutup, untuk menjalankan agama dan kepercayaannya dalam kegiatan ibadah, penataan, pengamatan, dan pengajaran." Selanjutnya dalam Pasal 20 ayat (2) Konvenan Internasional Hak Sipil dan Politik menyatakan "Segala tindakan yang menganjurkan kebencian atas dasar kebangsaan, ras atau agama yang merupakan hasutan untuk melakukan diskriminasi, permusuhan atau kekerasa, harus dilarang oleh hukum.

Penegasan atas jaminan kebebasan beragama dan berkeyakinan pun juga ditegaskan dalam Deklarasi Penghapusan Segala Bentuk Intoleransi dan Diskriminasi (International Convention on the Elimination of All Forms of Racial Discrimination). Artinya, tindakan mendeskriditkan atau bahkan mengesampingkan hak atas nama agama dan keyakinan merupakan bagian dari diskriminasi yang juga dilarang oleh kesepakatan internasional.

Berdasarkan beberapa dokumen HAM internasional tersebut, jaminan atas kebebasan beragama dan berkeyakinan merupakan kewajiban yang harus dipenuhi oleh negara. Negara wajib hadir dalam rangka memberikan jaminan pemenuhan atas seperangkat hak yang telah diakomodir oleh dokumen HAM internasional. Salah satu perwujudannya adalah memberikan pengakuan atas eksistensinya, sebagai kata kunci pemenuhan hak atas kebebasan beragama dan berkeyakinan.

\section{Politik Hukum Negara atas Rekognisi Penghayat Kepercayaan}

Suatu mekanisme penciptaan peraturan perundang-undangan salah satunya dibentuk melalui politik hukum yang dikehendaki para penguasa pada masa tersebut. Sehingga mekanisme penciptaan hukum yang ada di Indonesia saat ini adalah berdasarkan kehendak dan kewenangan pemegang tampuk kekuasaan. Politik Hukum dapat dijabarkan sebagai kemauan atau kehendak negara terhadap hukum. Politik hukum adalah kebijakan pemerintah mengenai hukum mana yang akan dipertahankan, hukum mana yang akan diganti, hukum mana yang akan direvisi dan hukum mana yang akan dihilangkan. Dengan demikian melalui politik hukum, negara membuat suatu rancang bangun pembangunan hukum nasional di Indonesia.

Sunaryati Hartono melihat politik hukum sebagai sebuah alat (tool) atau sarana dan langkah yang dapat digunakan oleh pemerintah untuk menciptakan 
sistem hukum nasional yang dikehendaki dan dengan sistem hukum nasional itu akan diwujudkan cita-cita bangsa Indonesia. ${ }^{30}$ Sedangkan Satjipto Rahardjo mendefinisikan politik hukum sebagai aktivitas memilih dan cara yang hendak dipakai untuk mencapai suatu tujuan sosial dan hukum tertentu dalam masyarakat. ${ }^{31}$ Sedangkan Mahfud MD mendefinisikan politik hukum sebagai legal policy atau garis kebijakan resmi yang hendak diterapkan atau dilaksanakan baik dengan pembuatan hukum baru maupun penggantian hukum lama dalam rangka mencapai tujuan negara. ${ }^{32}$

Konsepsi politik hukum tersebut menjadi penting didudukan sebagai kerangka (frame) dalam melihat arah kebijakan negara terhadap pengaturan penghayat kepercayaan dalam konteks negara hukum di Indonesia. Apa dan bagaimana upaya negara dalam memberikan pengaturan serta memberikan perlindungan terhadap penghayat kepercayaan sebagai bagian dari indeks kewarganegaraan di Indonesia. Berdasarkan perspektif politik hukum itulah, bagian ini berusaha membentangkan garis kebijakan negara dalam hal penghayat kepercayaan yang telah dimanifestasikan dalam bentuk peraturan perundangundangan. Dari bentangan tersebut, dapat dilihat adakah penyimpangan. Jikalaupun ada sejauh mana penyimpangan tersebut telah terjadi.

Dalam bingkai politik hukum tersebut, perihal pengakuan (rekognisi) terhadap penghayat kepercayaan, yang menjadi bagian integral dalam aspek hak asasi manusia di bidang kebebasan beragama dan berkeyakinan, seringkali diperdebatkan. Konsep tersebut memiliki aneka makna yang harus secara jelas diklarifikasi agar tidak menimbulkan kebingungan dan bias pemaknaan. Upaya dalam menjernihkan varian makna "pengakuan" yang berbeda di ranah kebebasan beragama dan berkeyakinan tidak cukup dengan upaya akademis semata. Dalam kasus-kasus praktis kerapkali ditemukan kesalahpahaman yang meluas tentang pengakuan kebebasan dalam peran negara. ${ }^{33}$ Kesalahpahaman tersebut dapat menghambat pemenuhan kebebasan beragama dan berkeyakinan dalam arah pembangunan sekaligus pengembangan hukum ke depan.

Di negara Indonesia, ideologi Pancasila serta ketentuan konstitusi telah mengakui akan pentingnya kebebasan memeluk agama dan berkeyakinan bagi warga negaranya. Pancasila sebagai ideologi Negara Republik Indonesia telah merepresentasikan semangat yang muncul ketika masa kemerdekaan. Tepatnya,

30 Sunaryati Hartono, Politik Hukum Menuju Satu Sistem Hukum Nasional (Bandung: Alumni, 1991), 1.

31 Satjipto Raharjo, Ilmu Hukum (Bandung: Citra Aditya Bakti, 2000), 35.

32 Mahfud MD, Politik Hukum Di Indonesia (Jakarta: Rajawali Pers, 2009), 1.

33 Heiner Bielefeldt, Politik Kesetaraan; Dimensi-Dimensi Kebebasan Beragama Dan Berkeyakinan (Bandung: Mizan, 2019), 45-46. 
ketika pilihan pembentukan dan formulasi negara yang tidak didasarkan atas suatu agama tertentu. Pilihan tersebut merupakan pilihan sekaligus hasil pikir yang mendalam para founding father sebagai landasan dalam sikap berbangsa dan bernegara. ${ }^{34}$ Kenyataan sejarah tersebut dipertegas dalam rumusan konstitusi sebagai landasan penyelenggaraan negara. UUD 1945 secara tegas menjamin kebebasan beragama dan berkeyakinan, sebagaimana yang dicantumkan dalam Pasal 28 E UUD 1945, yang pada ayat (1) dinyatakan bahwa, "setiap orang bebas memeluk agama dan beribadat menurut agamanya...", selanjutnya pada ayat (2) dinyatakan "setiap orang berhak atas kebebasan meyakini kepercayaan...". bahkan jaminan kebebasan beragama dan berkeyakinan tersebut disebut lagi dalam Bab lain dengan Pasal berbeda. Tepatnya pada Pasal 29 UUD 1945 yang menyatakan dengan tegas bahwa negara menjamin kemerdekaan tiap-tiap penduduk untuk memeluk agamanya masing-masing dan beribadat menurut agama dan kepercayaannya itu.

Sekalipun demikian, sayangnya rumusan norma konstitusi tersebut pada tataran selanjutnya menjadi ambigu setelah diaturnya pembatasan hak asasi dan pengecualian atas hak kebebasan beragama dan berkeyakinan di Indonesia. Pembatasan hak tersebut diatur dalam Pasal 28 J Ayat (2) UUD NRI Tahun 1945 yang berbunyi, "Dalam menjalankan hak dan kebebasannya, setiap orang wajib tunduk kepada pembatasan yang ditetapkan dengan undang-undang dengan maksud semata-mata untuk menjamin pengakuan serta penghormatan atas hak dan kebebasan orang lain dan untuk memenuhi tuntutan yang adil sesuai dengan pertimbangan moral, nilai-nilai agama, keamanan, dan ketertiban umum dalam suatu masyarakat demokratis." Keberadaan Pasal 28 J Ayat (2) tersebut menjadi pembatas atas jaminan hak-hak dalam Pasal-pasal di dalam UUD Tahun 1945. Diakomodirnya pasal perihal pembatasan hak tersebut mendorong terhadap ambiguitas perlindungan, penghormatan, dan pemenuhan hak kebebasan beragama dan berkeyakinan yang telah dijamin konstitusi.

Dalam praktek pengejawantahan norma konstitusi tersebut ke dalam bentuk peraturan perundang-undangan di bawahnya, juga telah memunculkan ketidakjelasan perlindungan, penghormatan, dan pemenuhan hak kebebasan beragama dan berkeyakinan. ${ }^{35}$ Derivasi pengaturan HAM dalam norma konstitusi secara vertikal seringkali mengalami pasang surut yang dipengaruhi oleh konfigurasi politik, 36 termasuk dalam kaitannya dengan kebebasan beragama dan

34 Amin Abdullah, "Kebebasan Beragama Atau Berkryakinan Dalam Perspektif Kemanusiaan Universal, Agama-Agama, Dan Keindonesia," in Makalah Training HAM Lanjutan Untuk Dosen Hukum Dan HAM (Training HAM lanjutan Untuk Dosen Hukum dan HAM, Yogyakarta, 2011), 14.

35 M Syafi'i, “Ambiguitas Hak Kebebasan Beragama Di Indonesia Dan Posisinya Pasca Putusan Mahkamah Konstitusi," Jurnal Konstitusi 8, no. 5 (Oktober 2011): 679.

36 Majda El Muhtaj, Hak Asasi Manusia Dalam Konstitusi Indonesia Dari UUD 1945 Sampai Dengan Perubahan UUD 1945 Tahun 2002 (Jakarta: Kencana Prenada Media, 2015), 110. 
berkeyakinan. Salah satu faktanya, hadirnya UU No. 1/ PNPS/ 1965 Tentang Pencegahan Penyalahgunaan dan/atau Penodaan Agama ini berdampak pada peniadaan hak beragama dan berkeyakinan bagi agama dan keyakinan yang berbeda dengan tafsir dari pengurus lembaga-lembaga agama resmi. Konsekuensi yuridisnya bahwa konsep agama bergeser menjadi konsep agama dan keyakinan yang harus ditentukan secara otoritatif oleh negara, dan meyakini agama dan kepercayaan yang tidak diakui secara resmi oleh lembaga-lembaga tersebut menjadi tidak lagi memiliki hak.

Dampak lain yang muncul ketika agama dan keyakinan sudah didefinitifkan oleh otoritas negara melalui lembaga-lembaga keagamaan resmi, prosedur administrasi pemerintahan hanya memberikan pelayanan kepada mereka-mereka yang agama dan kepercayaannya diakui oleh negara. Kementerian Agama dan Kementerian Dalam Negeri hanya akan memberi layanan KTP, Kartu Keluarga, SIM, Pencatatan Perkawinan, Paspor, SKCK, serta dokumen-dokumen lainnya kepada mereka yang menganut agama resmi, dan tidak kepada agama dan penganut kepercayaan lainnya. Situasi dan kondisi tersebut menyebabkan hilangnya hak-hak warga negara yang beragama tidak resmi terhadap pemenuhan kewajiban pemerintah, baik dalam bidang kesehatan, pendidikan, kesejahteraan, politik, dan bidang lainnya

Selanjutnya, dalam kaitannya dengan pengaturan dan pendataan status agama dan kepercayaan, UU No. 23 Tahun 2006 Tentang Administrasi Kependudukan jo UU No. 24 Tahun 2013, memberikan pengaturan sebagaimana dalam Pasal 61. Ketentuan Pasal 61 ayat (1) menjelaskan, "KK memuat keterangan mengenai kolom nomor KK, nama lengkap kepala keluarga dan anggota keluarga, NIK, jenis kelamin, alamat, tempat lahir, tanggal lahir, agama, pendidikan, pekerjaan, status perkawinan, status hubungan dalam keluarga, kewarganegaraan, dokumen imigrasi, nama orang tua". Pada rumusan Pasal 61 Ayat (1) tersebut memberikan batasan terhadap agama sebagaimana yang dimaksud dalam Pasal a quo. Yang dimaksud dengan agama dalam rumusan pasal tersebut adalah agama-agama yang hanya diakui oleh peraturan perundang-perundangan. Oleh karenanya untuk mengakomodir agama dan/atau kepercayaan yang tidak masuk dalam kategori agama resmi diatur dalam Pasal 61 Ayat (2), yang menjelaskan bahwa, "Keterangan mengenai kolom agama sebagaimana dimaksud pada ayat (1) bagi Penduduk yang agamanya belum diakui sebagai agama sesuai dengan ketentuan Peraturan Perundang-Undangan atau bagi penghayat kepercayaan tidak diisi, tetapi tetap dilayani dan dicatat dalam database kependudukan".

Bahkan lebih lanjut, pengosongan kolom agama dalam KTP elektronik bagi penganut agama dan kepercayaan yang tidak diakui berimbas pada akses untuk mendapatkan hak-hak dasar lainnya, seperti hak pendidikan, hak atas pekerjaan, hak atas kesehatan, hak atas jaminan sosial beserta seluruh layanan kependudukan. Dengan demikian sistem administrasi kependudukan sebagaimana diatur dalam UU 
Administrasi Kependudukan ini telah menimbulkan diskriminasi terhadap kesetaraan ruang kontestasi kewargaan, khususnya bagi penganut dan/atau penghayat kepercayaan, untuk mendapatkan hak-hak kewarganegaraan yang dijamin oleh konstitusi di Indonesia.

\section{Politik Hukum MK dalam Upaya Rekognisi Penghayat Kepercayaan dan}

\section{Implikasinya terhadap Kontestasi politik Kewargaan}

Mahkamah Konstitusi (MK) mengabulkan permohonan judicial review aturan pengosongan kolom agama bagi penganut kepercayaan pada KK dan KTP elektronik yang diatur dalam Pasal 61 ayat (1) dan (2) dan Pasal 64 ayat (1) dan (5) UndangUndang Nomor 23 Tahun 2006 tentang Administrasi Kependudukan sebagaimana telah diubah dengan Undang-Undang Nomor 24 Tahun 2013 tentang UU tentang Perubahan atas Undang-Undang Nomor 23 Tahun 2006 tentang Administrasi Kependudukan (UU Adminduk).

Ketentuan tersebut sebagaimana dalam UU Administrasi Kependudukan pada intinya mengatur bahwa dalam pendataan KK dan KTP-el bagi penduduk yang agamanya belum diakui oleh peraturan perundang-undangan atau bagi penghayat kepercayaan "tidak diisi", tetapi tetap dilayani dan dicatat dalam data base kependudukan. Kaitannya dengan hal itu, para pemohon dalam gugatannya berargumentasi bahwa pasal-pasal tersebut telah menyebabkan kerugian hak-hak konstitusional para pemohon. Rumusan dan ketentuan di dalam UU Administrasi Kependudukan membuktikan adanya keengganan negara mengakui keberadaan para penganut kepercayaan dikatakan sebagai tindakan diskriminasi secara langsung terhadap para pemohon yang merupakan para penganut kepercayaan.

Permohonan judicial review yang diajukan oleh Nggay Mehang Tana, Pagar Demanra Sirait, Arnol Purba, dan Carlim sebagai pemohon dengan Nomor Perkara 97/PUU-XIV/2016 dikabulkan seluruhnya oleh Majelis Hakim Mahkamah Konstitusi. Dalam putusannya, Majelis Hakim berpendapat bahwa kata "agama" dalam Pasal 61 ayat (1) dan Pasal 64 ayat (1) bertentangan dengan Undang-Undang Dasar Negara Republik Indonesia Tahun 1945 (UUD NRI 1945) dan tidak mempunyai kekuatan hukum mengikat secara bersyarat sepanjang tidak termasuk penganut aliran kepercayaan. Selain itu, Majelis Hakim MK juga menyatakan bahwa Pasal 61 ayat (2) dan Pasal 64 ayat (5) bertentangan dengan UUD NRI 1945 dan tidak mempunyai kekuatan hukum mengikat. Dengan demikian, penganut kepercayaan sejak putusan dibacakan hakim MK, memiliki kedudukan hukum yang sama dengan pemeluk enam agama yang telah diakui pemerintah dalam memperoleh hak terkait administrasi kependudukan. 
Melalui Putusan Mahkamah Konstitusi No. 97/PUU-XIV/2016, secara tegas MK mengabulkan permohonan para pemohon secara keseluruhan. ${ }^{37}$ Setidaknya jika ditelusuri secara mendalam dari Putusan MK tersebut, MK telah meletakkan tiga pilar penting jaminan konstitusional terhadap penghayat kepercayaan, dan menempatkannya setara dengan hak beragama dalam kontestasi politik kewarganegaraan di Indonesia.

Pertama, putusan No. 97/PUU-XIV/2016 menyebutkan bahwa kata "agama" dalam Pasal 61 ayat (1) \& (2) dan Pasal 64 ayat (1) \& (5) UU Administrasi kependudukan bertentangan dengan konstitusi dan dinyatakan tidak mempunyai kekuatan hukum mengikat, sepanjang tidak termasuk "kepercayaan." Dalam melakukan penemuan hukum konstitusi, MK menggunakan penafsiran original intent $^{38}$ dari rumusan Pasal 29 UUD 1945 untuk mempertegas gagasan awal tentang istilah "kepercayaan" sebagai bagian yang tidak terpisahkan dari istilah "agama" dalam konstitusi Indonesia. ${ }^{39}$

Kedua, Putusan No. 97/PUU-XIV/2016 ini mempertegas hak atas agama, termasuk kepercayaan, adalah hak konstitusional warga (constitutional rights) dan merupakan bagian dari hak asasi manusia. Hak tersebut bersifat "natural rights," yaitu hak alamiah pada setiap manusia yang tidak bisa dikurangi dalam keadaan apa pun. Dalam konteks ini, MK mempertegas posisi negara sebagai pengemban tanggung jawab (duty bearers) untuk memenuhi, melindungi, dan menghormati setiap individu penghayat kepercayaan sebagai pemegang hak (rights holders).

Ketiga, Putusan No. 97/PUU-XIV/2016 tersebut meletakkan prinsip kepastian hukum dan persamaan di depan hukum sebagai dasar menguji konstitusionalitas UU Administrasi Kependudukan. MK menguji pelaksanaan prinsip-prinsip tersebut secara substantif, yaitu bahwa pengosongan kolom agama bagi penghayat

37 Pengujian Undang-Undang No. 23 Tahun 2006 Terhadap UUD 1945, No. Putusan MK No. 97/PUU-XIV/ 2016 (Mahkamah Konstitusi November 7, 2017).

38 Penafsiran originalis ini menitikberatkan pada penilaian pertentangan norma hokum berdasarkan pada original meaning atau original intent yaitu mencoba menghadirkan semangat awal terbentuknya konstitusi tertulis lewat perdebatan-perdebatan pada saat penyusunan UUD, mendasarkan pada pemahaman dan tujuan konstitusi dari pendapat para penyusun konstitusi, originalis melihat beberapa sumber diantaranya pandangan framers of constitution termasuk tulisantulisan terdahulu pada penyusun konstitusi, artikel-artikel pada koran ketika konstitusi dibentuk, notulensi persidangan dalam pembentukan konstitusi, misalnya catatan persidangan BPUPKI dalam pembentukan UUD 1945, cacatan-catatan perumusan norma UUD 1945 amandemen. Tanto Lailam, "Penafsiran Konstitusi Dalam Pengujian Konstitusionalitas Undang-Undang Terhadap Undang-Undang Dasar 1945," Jurnal Media Hukum 21, no. 1 (June 2014): 95-96.

${ }^{39}$ Baca dalam Urgensi Penerapan Konsep Godly Constitution (Konstitusi dengan berdasar nilai ketuhanan) dalam Pengujian Perkara Konstitu.ional di Mahkamah Konstitusi, A.H. As'ari Taufiqurrohman, Laporan Penelitian: Urgensi Penerapan Konsep Godly Constitution (Konstitusi Dengan Berdasar Nilai Ketuhanan) Dalam Pengujian Perkara Konstitusional Di Mahkamah Konstitusi (Jakarta: Kepaniteraan dan Sekretariat Jenderal Mahkamah Konstitusi, 2018). 
kepercayaan di dalam KK dan KTP elektronik melahirkan ketidakjelasan status hukum dalam administrasi kependudukan. Pengaturan tersebut melahirkan ketidakpastian hukum, melanggar prinsip persamaan di depan hukum, dan bersifat diskriminatif.

Tiga pilar Putusan tersebut di atas sejatinya merupakan koreksi mendasar tentang posisi status kewarganegaraan (citizenship) penghayat kepercayaan untuk diletakkan kembali secara utuh sebagai warga negara. Status kewarganegaraan yang utuh adalah pintu masuk bagi penghayat kepercayaan untuk berpartisipasi secara setara dengan kelompok masyarakat lainnya dalam kehidupan berbangsa dan bernegara. Artinya, dasar ratio legis (pertimbangan hukum) Putusan MK No. 97/PUU-XIV/2016 sebenarnya adalah melakukan penolakan segala bentuk diskriminasi.

Oleh karenanya, eksistensi penghayat kepercayaan, berdasarkan keputusan MK tersebut menjadi lebih legitimate. Negara atau pemerintah diwajibkan memberikan pengakuan, jaminan, bahkan perlindungan bagi para penghayat kepercayaan selama ini. Dengan demikian, penghayat kepercayaan memiliki posisi yang setara dengan penganut agama lain, sebagaimana agama yang resmi berdasarkan peraturan perundang-undangan dalam ruang kontestasi politik kewarganegaraan di Indonesia.

Kewarganegaraan merupakan platform politik fundamental yang seringkali dicirikan dengan pemenuhan hak-hak formal yang dimiliki oleh warga negara dan kapasitas warga negara untuk benar-benar terpenuhinya hak-hak formal yang dimilikinya sebagai warga negara. ${ }^{40}$ Oleh karenanya, kewargenegaraan dan HAM merupakan konsep yang saling berkaitan. Konsep kewarganegaraan dan HAM keduanya muncul dari tradisi filosofis yang memprioritaskan ide kesetaraan dan hak-hak alamiah. ${ }^{41}$

Merujuk pada frame kewarganegaaran yang dikemukakan Kristian Stokke, bahwa identifikasi dimensi kewarganegaraan memiliki empat kata kunci, yakni; dimensi keanggotaan (membership), status legal, hak-hak, dan partisipasi. ${ }^{42}$ Pertama, berdasarkan dimensi keanggotaan. Konsep keanggotaan kewargaan dan secara lebih spesifik keangotaan kewarganegaraan senantiasa merumuskan konsep pembeda tegas antara "orang dalam" dan "orang luar" dalam sebuah komunitas warga

40 Ward Berenschot, Retna Hanani, and Prio Sambodho, "Mediasi Dan Hak Kewarganegaraan Dalam Akses Pelayanan Kesehatan Di Indonesia," in Citizenship in Indonesia; Perjuangan Atas Hak, Identitas, Dan Partisipasi (Jakarta: Yayasan Obor Indonesia, 2019), 115.

41 Vannessa Hearman, "Antara Kewarganegaraan Dan Hak Asasi Manusia: Perjuangan Meraih Keadilan Setelah Kekerasan Massal Tahun 1965 Di Indonesia," in Dalam Citizenship in Indonesia; Perjuangan Atas Hak, Identitas, Dan Partisipasi (Jakarta: Yayasan Obor Indonesia, 2019), 90.

42 Eric Hiarej and Kristian Stokke, Politik Kewargaan Di Indonesia (Jakarta: Yayasan Obor Indonesia, 2018), 25-37. 
negara. Sementara makna komunitas dan cara mengeksklusi bisa berbeda dari waktu ke waktu, dalam masyarakat modern kewargaan identik dengan keanggotaan dalam sebuah bangsa yang dianggap homogen, stabil, dan tertentu. Jika dikaitkan dengan problem penghayat kepercayaan pasca Putusan MK tersebut, maka status keanggotaan penghayat kepercayaan dalam kontestasi politik kewarganegaraan menjadi berubah. Penghayat kepercayaan yang selama ini mengalami diskriminasi akibat kosongnya kolom agama dalam KTP dan mengalami diskriminasi dalam pelayanan administrasi pemerintahan hingga sampai dengan potensi hilangnya hakhak dasar warga negara akan bergeser dengan upaya pengakuan negara dan pemenuhan hak oleh negara. Hal ini terjadi karena selama ini para penghayat kepercayaan dianggap sebagai "orang luar" (outsider) dalam konsep politik kewarganegaraan di Indonesia, khususnya jika dikaitkan dengan agama. Pasca putusan MK, para penghayat kepercayaan, secara hak, masuk menjadi bagian “orang dalam"(insider). Bahkan lebih tegas, pasca putusan MK tersebut tidak ada lagi pembeda antara konsep "orang luar" dan "orang dalam" dalam kontestasi kewarga negaraan di Indonesia. Baik penganut agama resmi berdasarkan peraturan perundang-undangan maupun para penghayat kepercayaan tidak ada batas pembeda lagi. Keduanya merupakan bagian dari entitas kewargaan di Indonesia yang sama-sama memiliki hak.

Kedua, status legal. Status legal merupakan atribut resmi yang diberikan negara kepada warga negaranya. Status legal inilah yang kemudian sebagai pintu masuk terjadinya hubungan kontraktual antara negara dengan warga negara dalam pemenuhan hak dan kewajiban. Jika dikaitkan dengan penghayat kepercayaan pasca putusan MK tersebut, penghayat kepercayaan akan mendapatkan status legal. Status legal dalam artian bahwa para penghayat kepercayaan akan diakui status legalnya sebagai penghayat kepercayaan dalam KTP, yang selama ini tidak pernah mendapatkan status legal sebagai penghayat kepercayaan. Dengan diakomodirnya kolom penghayat kepercayaan dalam dokumen kependudukan, seperti KTP elektronik dan KK, maka akan terbentuk sebuah hubungan kontraktual antara penghayat kepercayaan sebagai bagian dari warga negara dengan negara sebagai aktor politik yang berkewajiban memberikan perlindungan, pengakuan, jaminan, dan fasilitas-fasilitas pelayanan sosial lainnya. Hubungan kontraktual tersebut secara lebih lanjut dijabarkan dengan pemenuhan hak-hak bagi para penghayat keperrcayaan. Terutama hak-hak fundamnetal yang selama ini tidak pernah mereka rasakan sebagai bagian dari warga negara.

Ketiga, dimensi hak. Dimensi hak ini merupakan tindak lanjut dari dua dimensi sebelumnya, yakni dimensi keanggotaan dan dimensi status legal. Hak-hak kewarganegaraan (consitutional rights) yang merupakan hak-hak fundamental melekat pada kenggotaan dalam komunitas bangsa (warga negara) dan status legal yang diberikan oleh negara. Dalam praktiknya hak-hak ini tidak cukup dijamin dengan kepemilikan status legal dan perlu sebuah upaya perjuangan untuk 
mendapatkannya. Kaitannya dengan penghayat kepercayaan pasca putusan MK, maka para penghayat kepercayaan kini juga memiliki seperangkat hak yang juga harus dihadirkan oleh negara. Seperangkat hak itu harus diwujudkan oleh negara, seperti hak pendidikan, pelayanan kesehatan, dan pelayanan sosial lainnya. Selain itu para penghayat kepercayaan juga memiliki kewajiban untuk turut serta terlibat dalam partisipasi urusan publik, seperti kewajiban pajak, dan lain-lain.

Keempat, dimensi partisipasi. Dimensi ini merupakan dimensi yang paling luas dan merupakan konsekuensi dari dimensi-dimensi sebelumnya. Jika ketiga dimensi sebelumnya sudah terlaksana, maka dimensi partisipasi merupakan kelanjutan yang harus dihadirkan oleh negara. Melalui putusan MK tentang penghayat kepercayaan, para penghayat kepercayaan sekarang memiliki ruang partisipasi yang harus disediakan dan diakui oleh negara. Penghayat kepercayaan harus dilibatkan dalam urusan-urusan publik, menghadirkan eksistensinya dalam ruang deliberasi politik, hingga menjadi agenda sekaligus aktor dalam proses pembuatan kebijakan.

Selain pergeseran konsep politik kewarganegaraan yang dialami oleh penghayat kepercayaan melalui upaya rekognisi (pengakuan), putusan MK No. 97/PUU-XIV/2016 ini juga memberikan pergeseran dalam ruang keberagamaan di Indonesia. Pasca putusan MK tersebut, ruang kebebasan beragama di Indonesia mengalami pergeseran paradigma yang cukup mendasar. Selama ini, penghayat kepercayaan ditempatkan sebagai sebuah entitas budaya dan oleh karenanya haknya juga hanya diberikan dengan limitasi-limitasi tertentu. Dengan diputusnya putusan MK tersebut, MK telah melakukan koreksi atas politik hukum negara terkait kebebasan beragama dan berkeyakinan di Indonesia selama ini yang justru memunculkan praktik diskriminasi. MK menegaskan bahwa negara membedakan antara hak beragama dan hak meyakini kepercayaan. Negara dalam konstitusinya mengakui keduanya yang merupakan hak yang bersifat constitusional rights dan oleh karenanya bersifat fundamental. Dengan demikian negara memiliki kewajiban untuk memenuhi, melindungi, dan turut serta bertanggung jawab atas pengejawantahan hak tersebut.

Dengan demikian, dalam konteks kebebasan beragama, putusan MK ini memberi ruang terbuka bagi mekanisme berjalannya hak kebebasan beragama di Indonesia. Putusan MK ini memungkinkan negara untuk menjalankan komunikasi interpersonal dengan warga negara terkait isu-isu kebebasan beragama dan berkeyakinan di Indonesia. Bahkan, pasca putusan MK ini, kemungkinan komunikasi sebagai salah satu upaya meredam potensi konflik antar agama atau antara agama dengan penghayat kepercayaan menjadi menguat. Hal ini terjadi karena kesetaraan hak antara penganut agama dan penghayat kepercayaan mampu berperan dalam mengisi ruang-ruang politik kewarganegaraan. ${ }^{43}$ Jika selama ini

${ }^{43}$ Bielefeldt, Politik Kesetaraan; Dimensi-Dimensi Kebebasan Beragama Dan Berkeyakinan, 24. 
tafsir atas makna hak beragama selalu identik dengan mayoritas dan dengan mengatasnamakan status "agama resmi", oleh karenanya putusan MK berakibat hilangnya kecenderungan itu. Negara yang selama ini banyak melakukan upaya politis atas tafsir agama, dengan mengklaim penodaan agama dengan UU PNPS No. 1 Tahun 1965, dengan demikian hal tersebut tidak terjadi lagi, karena hak beragama dan meyakini kepercayaan merupakan hak yang fundamental dan wajib dilindungi oleh negara. ${ }^{4}$

Pertama, faktor hukum atau undang-undang, di mana Putusan Mahkamah Konstitusi Nomor 97/PUUXIV/2016 tentang Pengujian Undang-Undang Administrasi Kependudukan dapat menjadi dasar hukum bagi penghayat kepercayaan untuk melakukan pengisian penghayat kepercayaan pada kolom agama dalam KTP-el. Putusan Mahkamah Konstitusi Nomor 97/PUU-XIV/2016 tentang Pengujian Undang-Undang Administrasi Kependudukan yang dalam amar putusannya menentukan, bahwa kata "agama" tidak mempunyai kekuatan hukum mengikat secara bersyarat sepanjang tidak termasuk "Kepercayaan" dan Pasal 61 ayat (2) dan Pasal 64 ayat (5) perihal pengosongan kolom agama bagi penghayat kepercayaan bertentangan dengan UUD NRI 1945 dapat ditafsirkan jika faktor hukum melalui undang-undang sendiri maupun putusan Mahkamah Konstitusi menjadi faktor pendukung dalam implementasi pengisian kepercayaan dalam kolom agama bagi penghayat kepercayaan. Meskipun, dalam praktiknya untuk regulasi turunan, masih dibutuhkan regulasi lebih lanjut secara teknis guna memberikan kepastian hukum pada level implementasi, khususnya di daerah, mengingat putusan Mahkamah Konstitusi hanya melegitimasi, bahwa Undang-Undang Administrasi Kependudukan bertentangan dengan UUD NRI 1945, dan dibutuhkan sosialisasi putusan ini kepada masyarakat luas, khususnya bagi penghayat kepercayaan.

Kedua, faktor penegak hukum. Faktor yang kedua ini memiliki keterkaitan yang erat dengan faktor yang pertama, yaitu regulasi. Belum adanya peraturan atau petunjuk teknis terkait pelaksanaan putusan Mahkamah Konstitusi tersebut dari pusat menyebabkan Dinas Kependudukan dan Catatan Sipil belum dapat mengimplementasi Putusan Mahkamah Konstitusi Nomor 97/PUU-XIV/2016 tentang Pengujian Undang-Undang Administrasi Kependudukan tersebut meskipun terdapat penghayat kepercayaan yang mengajukan permohonan perubahan kolom isian agama, dari agama tertentu menjadi penghayat kepercayaan ataupun yang semula sebatas dikosongkan atau diberi tanda strip (-) menjadi penghayat kepercayaan.

Ketiga, faktor sarana atau fasilitas. Persoalan dalam faktor sarana dan prasarana yang terdapat berupa sistem aplikasi pilihan agama atau kepercayaan Bandung."

44 Oki Wahju, "Penghormatan Hak Asasi Manusia Bagi Penghayat Kepercayaan Di Kota Bandung. 
dalam pembuatan KTP-el. Meskipun sekarang sudah terdapat pilihan isian "penghayat kepercayaan" pada saat pembuatan KTP-el, namun Putusan Mahkamah Konstitusi Nomor 97/PUU-XIV/2016 tentang Pengujian Undang-Undang Administrasi Kependudukan belum dapat diimplementasi bagi penghayat kepercayaan, karena kepercayaan yang dianut dan diyakini oleh penghayat kepercayaan secara turun temurun ternyata tidak terdaftar secara resmi dalam birokrasi pemerintahan yang dilegitimasi dengan Peraturan Daerah sebagai pengakuan atas masyarakat adat yang memiliki kepercayaan.

Keempat, faktor masyarakat. Pada faktor masyarakat, diketahui bahwa pengisian kolom agama dengan agama tertentu pada KTP-el dilakukan karena adanya sikap pasrah, terpaksa ataupun tidak ada pilihan lain yang diberikan oleh aturan yang mengatur pembuatan KTP-el selama ini, meskipun sebagian dari penghayat kepercayaan sebenarnya menginginkan mencantumkan kepercayaan sesuai keyakinannya. Dibutuhkan kesadaran masyarakat, khususnya para penghayat kepercayaan, untuk turut serta aktif dalam melakukan proses pendataan administrasi kependudukan.

Kelima, faktor budaya. Faktor ini mencakup nilai-nilai yang mendasari hukum yang berlaku. Nilai-nilai yang menjadi dasar bagi implementasi putusan Mahkamah Konstitusi tersebut meliputi nilai-nilai hak asasi manusia dan asas-asas dalam pelayanan publik. Benturan dan konflik sosial budaya memiliki potensi, meskipun kecil, akan terjadi, yakni munculnya pandangan di kalangan tertentu yang menilai putusan Mahkamah Konstitusi ini akan menyuburkan kepercayaan yang selama ini ruang geraknya terbatas bahkan sudah ikut agama tertentu.

Dengan demikian, diperlukannya langkah-langkah konkret untuk mengimplementasi Putusan Mahkamah Konstitusi Nomor 97/PUU-XIV/2016 tentang Pengujian UU Administrasi Kependudukan dalam bentuk tindakan konkrit dan nyata negara dalam melakukan politik pengakuan dalam kontestasi kewarganegaraan di Indonesia. Selain itu, diperlukan juga sinergisitas di antara pihak terkait terkait keberadaan Putusan Mahkamah Konstitusi, sehingga setiap masyarakat dapat mengetahui keberadaan Putusan Mahkamah Konstitusi tersebut.

Lebih jauh, di masa mendatang upaya memperkuat rekognisi identitas sebagai indeks kewargaan menjadi suatu keniscayaan yang tidak bisa ditawar lagi oleh Negara. Pada era interkoneksi global di masa sekarang ini, realitas kebutuhan terhadap politik rekognisi identitas kewargaan harus mengalami penguatan dan tidak hanya dimaknai secara meso, artinya sebatas dimaknai sebagai relasi negara dengan warga negara semata, melainkan sebagai upaya politik yang melampui dan menembus sekat lintas-batas negara. ${ }^{45}$

45 Fachri Aidulsyah, "Islamisme Dan Politik Kewargaan Di Indonesia," Jurnal LIPI Masyarakat Indonesia Majalah Ilmu-Ilmu Sosial Indonesia 44, no. 1 (June 2018): 138. 


\section{KESIMPULAN}

Putusan MK No. 97/PUU-XIV/2016 sejatinya merupakan koreksi mendasar tentang posisi status kewarganegaraan (citizenship) penghayat kepercayaan untuk diletakkan kembali secara utuh sebagai warga negara. Status kewarganegaraan yang utuh adalah akses utama pemenuhan HAM bagi penghayat kepercayaan untuk berpartisipasi secara setara dan adil dengan kelompok masyarakat lainnya dalam kehidupan berbangsa dan bernegara.

Selain pergeseran konsep poli tik kewarganegaraan yang dialami oleh penghayat kepercayaan melalui upaya rekognisi, Putusan MK tersebut juga memberikan pergeseran dalam ruang keberagamaan di Indonesia. Pasca putusan MK tersebut, ruang kebebasan beragama di Indonesia mengalami pergeseran paradigma yang cukup mendasar. Dengan diputusnya perkara tersebut, MK telah melakukan koreksi atas politik hukum negara terkait kebebasan beragama dan berkeyakinan di Indonesia selama ini yang justru memunculkan praktik diskriminasi. MK menegaskan bahwa Negara selama ini telah mendikotomikan antara hak beragama dan hak meyakini kepercayaan. Negara dalam konstitusinya mengakui keduanya yang merupakan hak yang bersifat constitusional rights dan oleh karenanya bersifat fundamental. Dengan demikian negara memiliki kewajiban untuk memenuhi, melindungi, dan turut serta bertanggung jawab atas pengejawantahan hak tersebut.

Sebagai tindak lanjut Putusan MK, Pemerintah harus memberikan perlindungan dan jaminan atas pengakuan terhadap agama dan penghayat kepercayaan yang dimiliki oleh warga negara sebagai hak fundamental (constitusional rights) dalam kehidupan berbangsa dan bernegara di Indonesia. Konsep perlindungan, pengakuan, dan pemberian jaminan atas eksistensi keberadaan agama dan kepercayaan harus diwujudkan dalam seluruh pelayanan pemerintahan, baik dalam tataran regulasinya, konsep dan sistemnya, hingga sampai pada ranah implementasinya di masyarakat.

\section{DAFTAR PUSTAKA}

Abdullah, Amin. "Kebebasan Beragama Atau Berkryakinan Dalam Perspektif Kemanusiaan Universal, Agama-Agama, Dan Keindonesia." In Makalah Training HAM Lanjutan Untuk Dosen Hukum Dan HAM, 14. Yogyakarta, 2011. Aidulsyah, Fachri. "Islamisme Dan Politik Kewargaan Di Indonesia." Jurnal LIPI Masyarakat Indonesia Majalah Ilmu-Ilmu Sosial Indonesia 44, no. 1 (June 2018): 138. 
Alimin, Asep, and M. Ariez Musthofa. "Hubungan Antara Ingroup Favoritism Dan Perilaku Sosial." Jurnal Psikologi Insight 3, no. 1 (April 2019): 32-45.

Baderin, Mashood A. Hukum Hak Asasi Manusia Dan Hukum Islam. Jakarta: Komisi Nasional Hak Asasi Manusia, 2010.

Berenschot, Ward, Retna Hanani, and Prio Sambodho. "Mediasi Dan Hak Kewarganegaraan Dalam Akses Pelayanan Kesehatan Di Indonesia." In Citizenship in Indonesia; Perjuangan Atas Hak, Identitas, Dan Partisipasi, 115. Jakarta: Yayasan Obor Indonesia, 2019.

Bielefeldt, Heiner. Politik Kesetaraan; Dimensi-Dimensi Kebebasan Beragama Dan Berkeyakinan. Bandung: Mizan, 2019.

Damami, Mohammad. Kepercayaan Terhadap Tuhan Yang Maha Esa Dewasa Ini. Yogyakarta: Pustaka Pelajar, 2018.

- - - Kepercayaan Terhadap Tuhan Yang Maha Esa Periode 1973-1983; Sebuah Sumbangan Pemahaman Tentang Proses Legalisasi Konstitusional Dalam Konsteks Pluralitas Keberagaman Di Indonesia. Jakarta: Kementerian Agama, 2011.

dokumen International Convenant on Civil and Political Right, § Pasal 18 (n.d.).

El Muhtaj, Majda. Hak Asasi Manusia Dalam Konstitusi Indonesia Dari UUD 1945 Sampai Dengan Perubahan UUD 1945 Tahun 2002. Jakarta: Kencana Prenada Media, 2015.

Hartono, Sunaryati. Politik Hukum Menuju Satu Sistem Hukum Nasional. Bandung: Alumni, 1991.

Hasanuddin, Iqbal. "Hak Atas Kebebasan Beragama/Berkeyakinan: Sebuah Upaya Pendasaran Filosofis." SOCIETAS DEI 4, no. 1 (April 2017): 97-98.

Hearman, Vannessa. "Antara Kewarganegaraan Dan Hak Asasi Manusia: Perjuangan Meraih Keadilan Setelah Kekerasan Massal Tahun 1965 Di Indonesia." In Dalam Citizenship in Indonesia; Perjuangan Atas Hak, Identitas, Dan Partisipasi, 90. Jakarta: Yayasan Obor Indonesia, 2019.

Hiarej, Eric, and Kristian Stokke. Politik Kewargaan Di Indonesia. Jakarta: Yayasan Obor Indonesia, 2018.

HS, Salim, and Erlies Septiana. Penerapan Teori Hukum Pada Penelitian Tesis Dan Disertasi. Jakarta: Rajawali Pers, 2013.

Kartapradja, Kamil. Aliran Kebatinan Dan Kepercayaan Di Indonesia. Jakarta: Masagung, 1985.

Kejaksaan Agung RI. Pokok-Pokok Pola Pelaksanaan Tugas Pakem. Jakarta: Kejaksaan Agung RI, 1985.

Lailam, Tanto. "Penafsiran Konstitusi Dalam Pengujian Konstitusionalitas Undang-Undang Terhadap Undang-Undang Dasar 1945." Jurnal Media Hukum 21, no. 1 (June 2014): 95-96.

MD, Mahfud. Politik Hukum Di Indonesia. Jakarta: Rajawali Pers, 2009.

Nurdjana, IGM. Hukum Dan Aliran Kepercayaan Menyimpang Di Indonesia. Yogyakarta: Pustaka Pelajar, 2009.

Oki Wahju. "Penghormatan Hak Asasi Manusia Bagi Penghayat Kepercayaan Di Kota Bandung" 7, no. 1 (July 2016).

Pencegahan Penyalahgunaan dan/atau Penodaan Agama, Pub. L. No. Penetapan Presiden No. 1 Tahun 1965, § Pasal 1 (n.d.). 
Pengujian Undang-Undang No. 23 Tahun 2006 Terhadap UUD 1945, No. Putusan MK No. 97/PUU-XIV/2016 (Mahkamah Konstitusi November 7, 2017).

Peraturan Pemerintah (PP) tentang Pelaksanaan Undang Undang Nomor 23 Tahun 2006 Tentang Administrasi Kependudukan, Pub. L. No. PP No 37 Tahun 2007, $\S$ Pasal 1 (n.d.).

Raharjo, Satjipto. Ilmu Hukum. Bandung: Citra Aditya Bakti, 2000.

Rasyidi, HM. Islam Dan Kebatinan. Jakarta: Yayasan Islam Studi Club Indonesia, 1967.

Rofiq, Ahmad Chairul. “Ahmad Chairul Rofiq, Kebijakan Pemerintah Terkait Hak Sipil Penghayat Kepercayaan Dan Impikasinya Terhadap Perkembangan Penghayat Kepercayaan Di Ponorogo." Kodifikasia 8, no. 1 (2014): 3.

Saut, Prins David. “Ada 187 Organiasasi dan 12 Juta Penghayat Kepercayaan di Indonesia." Detik.com, November 2017. https:/ / news.detik.com/berita/3720357/ada-187-organisasi-dan-12-juta-penghayatkepercayaan-di-indonesia. 2008.

Smith, Rhoma K.M. Hukum Hak Asasi Manusia. Yogyakarta: PUSHAM UII,

Smith, Wilfred Cantwel. The Meaning and End of Religion. Virginia: Macmillan, 1963.

Subagya, Rahmat. Kepercayaan (Kebatinan, Kerohanian, Kejiwaan) Dan Agama. Yogyakarta: Kanisius, 1976.

Syafi'i, M. “Ambiguitas Hak Kebebasan Beragama Di Indonesia Dan Posisinya Pasca Putusan Mahkamah Konstitusi." Jurnal Konstitusi 8, no. 5 (Oktober 2011): 679.

Taufiqurrohman, A.H. As'ari. Laporan Penelitian: Urgensi Penerapan Konsep Godly Constitution (Konstitusi Dengan Berdasar Nilai Ketuhanan) Dalam Pengujian Perkara Konstitusional Di Mahkamah Konstitusi. Jakarta: Kepaniteraan dan Sekretariat Jenderal Mahkamah Konstitusi, 2018.

Tim Penyusun Kamus Pusat Bahasa. "Kamus Besar Bahasa Indonesia." Jakarta: Pusat Bahasa Departemen Pendidikan Nasional, 2018.

Undang-Undang Dasar Negara Kesatuan Republik Indonesia Tahun 1945, § Pasal 28 (n.d.).

Undang-undang Nomor 24 Tahun 2013 atas perubahan Undang-Undang Nomor 23 Tahun 2006 tentang Administrasi Kependudukan, Pub. L. No. UU No. 24 Tahun 2013 jo No. 23 Tahun 2016, § Pasal 61 Ayat (2); Pasal 64 Ayat (2) (n.d.).

Vickers, Lucy. Religious Freedom, Religious Discrimination and the the Workplace. USA: Hart Publishing, 2008. 